\title{
KETAKSAAN IDENTITAS GENDER DALAM CERPEN "SAYA DI MATA SEBAGIAN ORANG": ANALISIS TEORI QUEER
}

\section{GENDER AMBIGUITY IN "SAYA DI MATA SEBAGIAN ORANG": QUEER THEORY STUDY}

\author{
Sarwo Ferdi Wibowo \\ Kantor Bahasa Bengkulu \\ Jalan Zainul Arifin 2, Singaranpati, Kota Bengkulu 38221 \\ Pos-el: sarwoferdiwibowo.sfw@gmail.com
}

*) Naskah diterima: 2 Oktober 2019; direvisi: 15 November 2019; disetujui: 3 Desember 2019

\begin{abstract}
Abstrak
Studi tentang queer sedang berkembang pesat di dunia. Namun, dalam konteks Indonesia penelitian ini cenderung disalahpahami. Padahal dalam bidang sastra banyak karya sastra yang mengangkat persoalan yang dihadapi oleh kelompok ini. Penelitian ini bertujuan untuk mengungkap strategi penulis Indonesia, khususnya Djenar Maesa Ayu dalam cerpen "Saya di Mata Sebagian Orang dalam mengangkat permasalahan queer di Indonesia. Metode yang akan digunakan adalah matriks heteroseksualitas dan teori queer Judith Butler sebagai pisau analisis. Hasil penelitian menunjukkan bahwa cerpen SdMSO melucuti nuansa gender dalam kata sebagai perlawanan terhadap wacana bentukan heteronormativitas dengan wacana yang mendenaturalisasinya. Strategi ini dimaksudkan untuk meredam resistansi dari sidang pembaca dalam lingkungan yang belum cukup kondusif untuk membicarakan teori queer. Berkaitan dengan cara kerja matriks heteroseksualitas, tokoh aku dalam cerpen ini mampu mengatasi tekanan psikologis yang dihadapi dari isu di sekitarnya berkat solidaritas antar anggota queer. Hukuman sosial berupa isu malah semakin menguatkan keyakinan akan identitas gendernya tersebut.
\end{abstract}

Kata Kunci: ketaksaan gender, queer, Judith Butler, matriks heteroseksual.

\begin{abstract}
The study of queer is developing rapidly in the world. However in Indonesian context, this study tend to missunderstood. Yet in literture field, there is many object that raise issues that this group face. This study aims to reveal Indonesia writer strategy's, especially Djenar Maesa Ayu in Saya di Mata Sebagian Orang shortstory in order to discuss queer issues in Indonesia. Method that used is heterosexsuality matriks and Judith Butler's queer theory as analysis tools. The result shows that SdMSO remove gender nuance in words as a struggle against heteronormativity discourse with another discourse that denaturalized it. This strategi aims to drown out the reader resistence in environment that not conducive yet to discuss queer theory. Related to heterosexsuality matrix, the character in this shortstory be able to overcome psychological pressure that the character face thanks to queer intragroup solidarity. Social punishment like issues instead more empowering the character confidence to his/him gender identity.
\end{abstract}

Keywords: gender ambiguity, queer, Judith Butler, heterosexual matrix. 


\section{PENDAHULUAN}

Permasalahan utama yang dihadapi di Indonesia dalam lingkup studi gender adalah penerimaan queer dalam masyarakat Indonesia. Bahkan istilah queer sendiri masih kalah populer dibanding istilah lain, yaitu LGBT (lesbian, gay, biseksual, dan transgender). Kedua hal ini bahkan sering diidentikkan dan disalahpahamkan antara satu dan yang lainnya. Meski saling beririsan, konsep ini adalah dua rumusan yang berbeda.

Kuatnya cengkeraman wacana heteroseksual di Indonesia, tentu saja, yang didukung faktor budaya dan agama menjadi penyebab utama adanya resistansi terhadap kelompok queer. Sastra pun tidak lepas dari kecenderungan tersebut. Sastra secara praktik masih dipergunakan sebagai alat untuk mengukuhkan wacana heteronormativitas dalam masyarakat Indonesia. Namun sebagai wahana pertarungan ideologi, narasi perlawanan terhadap cengkeraman heteronormativitas diniscayakan muncul dalam sastra Indonesia. Ada banyak contoh yang bisa diajukan, misalnya Olenka karya Budi Darma, Supernova: Ksatria, Putri, dan Bintang Jatuh karya Dewi Lestari, dan beberapa karya lain baik novel maupun cerpen.

Karya-karya sastra yang menggunakan teori queer ini, sesuai dengan misi ideologi yang dimuatnya, bermaksud menggugat kategori identitas dan seksualitas agar menjadi konstruksi sosial yang diciptakan dalam wacana dari pada kategori biologis dan esensial. Gagasannya adalah mewajarkan pemaknaan baru gender yang merupakan produk sosial yang terus mengalami perubahan dan pemaknaan.

Sebagai kajian yang baru berkembang, belum banyak penelitian mengenai queer, apalagi dikaitkan dengan sastra. Beberapa peneliti Indonesia bahkan cenderung menggunakan analisis queer untuk menganalisis karya sastra barat. Untuk penelitian yang menerapkan teori queer pada objek karya sastra Indonesia sendiri masih terbilang jarang (untuk tidak mengatakan tidak ada), sehingga ada kerumpangan besar antara kajian sastra yang membutuhkan analisa teori queer dengan objek karya sastra dengan tema queer yang terus berkembang.

Penelitian ini, berusaha mengisi kerumpangan tersebut. Objek yang akan dikaji adalah cerpen Djenar Maesa Ayu berjudul "Saya di Mata Sebagian Orang" (selanjutnya disebut SdMSO). Djenar bersama Ayu Utami memang dikenal sebagai penulis yang konsisten mengangkat isu-isu feminis dalam karya mereka. Djenar tampaknya merasa perlu mengangkat tema queer dalam karyanya sebagai bentuk perjuangan identitas gender, karena itu SdSMO ini lahir.

Artikel ini akan membahas strategi narasi Djenar dalam menggambarkan identitas queer tokoh utama dalam cerpennya. Masalah yang akan dibahas dirumuskan sebagai pertanyaan berikut; Bagaimana strategi Djenar menarasikan tokoh utama dalam cerpennya untuk mengonstruksi identitas queer dalam cerpennya? Bersama itu pula akan disinggung mengenai latar sosial serta aspek-aspek lain yang berkaitan dengan pembentukan karakter tokoh utama yang berkaitan dengan keutuhan strategi narasi Djenar.

\section{TEORI}

\section{Identitas Queer dan Matriks Heteroseksualitas}

Queer pada mulanya adalah kosa-kata yang digunakan sebagai ejekan bagi kaum homoseksual (Barry, 2010:167). Istilah ini kemudian digunakan dalam bidang ilmiah sebagai studi queer yang berkenaan dengan kajian tentang gay atau lesbian. Namun, dalam perkembangannya, studi queer dipahami secara lebih luas sesuai landasan dasar identitas yang mereka gunakan, yaitu denaturalisasi identitas seksual Focault. Denaturalisasi identitas ini terkait dengan 
identitas gender, maskulin dan feminin yang tidak hanya ditentukan oleh bahan mentah biologis (jenis kelamin) melainkan batas-batas normatif identitas gender. Dalam hal ini identitas gender dapat saling melewati batas-batas normatif tersebut.

Memahami queer harus dimulai dari memahami konstruksi identitas gender dalam teori feminis. Gender merupakan konsep utama feminisme yang mempertentangkan antara femininitas dan maskulinitas sebagai hasil interpretasi budaya dengan perbedaan jenis kelamin secara biologis. Beauvoir, salah satu tokoh terkemuka feminisme, menyinggung persoalan ini dalam kalimat: "seseorang tidak dilahirkan sebagai perempuan, tetapi dibentuk menjadi perempuan." Kalimat ini merupakan penanda penting bagi sudut pandang feminis yang menganggap gender sebagai rumusan asimetris yang menempatkan laki-laki (maskulin) dengan perempuan (feminin) dalam posisi yang hierarkis. Namun kajian mengenai gender dapat memberikan fokus yang lebih 'inklusif' bagi kedua gender dalam analisis (Jackson, 2009:228).

Dua ulasan terdahulu dari Oakley (1972) dan Rubin (1975) dapat dikatakan sebagai konsep awal bagi gender. Oakley mendefinisikan gender tidak dibentuk secara biologis, melainkan secara sosial, kultural, dan psikologis, yaitu proses menjadi laki-laki atau perempuan dalam sebuah masyarakat tertentu dalam kurun waktu tertentu. Sementara itu menurut Rubin setiap masyarakat memiliki sistem gender yang diartikan sebagai "serangkaian aturan yang dengannya materi biologis mentah berupa jenis kelamin dan prokreasi manusia dibentuk oleh campur tangan sosial dan manusiawi." Oleh karena itu gender didefinisikan sebagai kategori seksual yang dipaksakan secara sosial sebagai hasil relasi seksualitas yang bersifat sosial (Rubin dalam Jackson, 2009:228-229).
Kedua pendapat tersebut memahami gender sebagai suatu konstruksi budaya. Oleh karena itu interpretasi ulang terhadap kategori gender juga merupakan sebuah keniscayaan. Jika gender bersifat sosial berarti identitas seksual tidak bersifat natural, sehingga dapat ditelusuri bagaimana ia membentuk persepsi mengenai jenis kelamin. Kita juga dapat mempertanyakan mengapa dan bagaimana dunia sosial dibagi ke dalam dua kelompok lelaki dan perempuan. Denaturalisasi identitas seksual inilah yang kemudian memberi ruang bagi munculnya teori queer.

Denaturalisasi identitas seksual merambah pada studi tentang kekacauan dan ketaksaan identitas gender dan seks. Individu yang merasa bertentangan dengan konvensi sosial dapat mengklaim dan diklaim sebagai queer. Berkaitan dengan denaturalisasi identitas seksual ini, teori queer tidak bisa dilepaskan dari pascamodernisme karena teori ini merupakan dekostruksi dari pembagian manusia ke dalam dua kategori gender. Salah satu tokoh yang fokus pada hal ini adalah Judith Butler. Alih-alih seorang feminis berpandangan radikal, Butler cenderung menggunakan pandangan pascamodern dalam analisisnya. Butler hanya bersepakat dalam hal gender merupakan hasil interpretasi sosial dibanding esensi biologis prasosial dengan kaum feminis. Analisisnya lebih menekankan pada penjelasan kultural dengan melihat laki-laki dan perempuan sebagai kategori yang dibentuk melalui wacana.

Untuk mendukung denaturalisasi terhadap identitas gender dan seks, Butler menjelaskan mengenai proses pembentukan subjek. Konsep ini didasarkan pada uraian discipline and punish milik Focault. Dalam bagian tersebut terdapat penjelasan mengenai kehadiran subjek yang diakibatkan alasan yuridis kekuasaan untuk mengatur hidup secara politis melalui pembatasan, 
pelarangan, regulasi, pengontrolan, dan bahkan perlindungan yang terkait dengan prasyarat tertentu yang telah ditentukan. Subjek dibentuk berdasarkan prasyarat tersebut. Salah satu prasyarat tersebut dibuat berdasarkan konsep heteroseksual dari pandangan esensial.

Perbedaan antara konsep pembentukan subjek Focault dan Butler terletak pada internalisasi. Pandangan Butler menganggap bahwa hukum telah menyatu dengan subjek, bukan diinternalisasikan. Dalam istilah Butler (2002:172) hukum/gender written in the body, sehingga subjek merupakan produk fiksi kekuasaan (Jagger, 2008:17-18).

Pendapat Butler di atas memiliki banyak kesamaan dengan Delphy. Konsep gendernya dapat diterjemahkan sebagai pembalikan logika mengenai seks dan gender. Bagi Delphy (dalam Jackson, 2009:233) bukan seks dan gender yang memproduksi heteroseksualitas melainkan heteroseksualitaslah yang memproduksi seks dan gender dalam bentuk biner. Pembedaan inilah yang kemudian digunakan dan memiliki implikasi bagi praktik-praktik sosial. Sebagai hasil tindakan/produk sosial, menurutnya tidaklah cukup memperlakukan isi gender sebagai sesuatu yang bisa berubah saat wadahnya tidak bisa diganti (dalam Jackson, 2009:234). Implikasinya, pembentukan kategori seksualitas lain (queer) diniscayakan karena ia merupakan produk sosial.

Analisis material Delphy inilah yang disuarakan kembali oleh Butler dalam dekonstruksinya. Bagi Butler kategori gender merupakan produk dari wacana pengetahuan atau kekuasaan. Jenis kelamin dibentuk melalui berbagai praktik diskursif dan nondiskursif. Tubuh adalah ruang yang terus menerus difantasikan dan difantastikkan. Pilcher (2004:8) menjelaskan tindakan memfantasikan tubuh dalam bertindak menghadirkan gender secara sosial. Tubuh baru bisa dimengerti jika digenderkan. Untuk digenderkan, tubuh diberi perlakuan gender yang terus menerus. Sehingga alihalih sebagai bagian inti dari diri kita, dia justru bersifat performatif (dalam Jackson, 2009:236). Perlakuan terus menerus ini lah yang menyebabkan gender sebagai sesuatu yang tidak tetap (Prabasmoro,2004:4).

Kecairan identitas gender ini memungkinkan individu memiliki kadar femininitas dan maskulinitas yang berbeda-beda, karenanya tidak ada satu individu pun yang sepenuhnya menjelma menjadi suatu gender tertentu. Gender seseorang tidak memberikan informasi tentang perilakunya, sebaliknya gender ditentukan oleh perilaku individu. Gender, seks (dalam pengertian hasrat), dan identitas gender merupakan hasil dari sesuatu yang dilakukan dan diekspresikan dalam waktu tertentu sehingga bersifat performatif dengan bentuk yang parsial dan situasional. Pendapat ini mengundang berbagai kritik yang menuduh Butler menyangkal materialitas tubuh.

Dalam bukunya yang berjudul Bodies that Matter ia menjawab kritik tersebut. Argumen jawabannya beralih dari performatif ke konsep performativitas dalam konsep linguistik. Performativitas dalam linguistik adalah konsep wacana dimana terjadi pengulang-ulangan konvensi (performativity) yang memiliki kekuasaan untuk menjadikan sesuatu sebagai kenyataan. Sebagai contoh adalah tuturan "saya nyatakan kalian berdua sebagai suami istri" yang secara sosial mewujudkan status pengantin sebagai pasangan. Dalam praktik pembentukan gender wacana yang digunakan adalah "anak anda laki-laki" jika memiliki penis atau "anak anda perempuan" jika memiliki vagina. Pengulangan-pengulangan konvensi ini oleh otoritas yang diberi kuasa merupakan sebab timbulnya compulsory heterosexuality. Bagi Butler hal ini merupakan usaha menaturalisasi wacana sehingga wacana 
pembagian biner untuk jenis kelamin menjadi sesuatu yang biasa. Berkaitan dengan pembentukan subjek pada bahasan sebelumnya, konsep perfomativitas menegaskan bahwa subjek diperangkap dalam kuasa wacana dan bahasa. Gagasan performativitas Butler (2002:81 - 82) menolak dualisme konstruksi gender yang dipaksakan heteronormativitas. Konsep oposisi biner seringkali menekankan pada salah satu oposisi yang dianggap utama dan alamiah. Lewat hal ini lah heteroseksualitas memperoleh statusnya sebagai orientasi yang diistimewakan sebagai konsep yang dianggap utama dan alamiah (privileged orientation).

Hal ini ikut ditegaskan oleh Rubin (dalam Alimi, 2004:38-39) heteroseksualitas tidak mendapatkan status tersebut karena kualitas inheren yang melekat padanya. Status tersebut didapat melalui pelabelan negatif terhadap praktik seksual lain. Konsep heteroseksual dinaturalisasi sementara orientasi seksual lain diabnormalisasi. Gayle Rubin merupakan feminis yang menggunakan Focault untuk memisahkan rumusan mengenai gender. Dia mengangkat masalah "jenis kelamin minoritas" yang terabaikan dalam analisis antara hubungan gender dan penindasan perempuan (Rubin, 1984). Ada kesadaran bahwa batasan-batasan identifikasi gender dan heteroseksualitas diawasi dengan cara yang berbeda-beda sehingga mereka yang keluar dari batasan tersebut distigmasisasi dan seringkali dihukum. Sehubungan dengan pengawasan batas-batas ini, pembagian gender dan heteroseksualitas normatif saling menguatkan. Tamsil Wilton (dalam Jackson, 2009:243) menjelaskan bahwa gay dan lesbian distigmatisasi dengan mempermasalahkan gender mereka; laki-laki dipaksa menjadi maskulin dengan ancaman diberi label banci atau perempuan yang tidak feminin distigmatisasi sebagai lesbian.
Perspektif Butler mengenai gender ini memberikan perubahan signifikan khususnya dalam cara memandang heteroseksualitas dan homoseksualitas. Pandangan kaum esensialis berpendapat bahwa perbedaan gender dengan mudah dapat dijelaskan melalui biologi reproduksi. Seksualitas memerlukan gender dalam arti manjadi feminin berarti tertarik pada laki-laki. Pandangan ini dipandang merupakan penjajahan seksualitas dan menegaskan maskulinitas. Dengan demikian perbedaan seksual menjadi esensial bagi hasrat seksual bahwa "yang berlawanan itu menarik" sehingga heteroseksualitas dikatakan normal.

Untuk memberikan alternatif bagi pandangan esensialis ini, beberapa feminis menggunakan teori psikoanalisis. Namun teori psikoanalisis memperlakukan jenis kelamin dan seks saling berkelindan sehingga sulit memahami konsep homoseksual secara positif. Dari sini, tulisan Focault menjadi penting untuk mendukung argumen feminis dan teoritisi queer. Ini karena karya Focault menyediakan kritik terhadap gagasan represi dan menyatakan bahwa tidak ada identitas terberi (given identity) dalam seksualitas yang terpisah dari konstruksi sosial budaya (Jackson, 2009:241).

Matriks heteroseksual merupakan konsep yang memberikan uraian tentang bagaimana gender dikonstruksi oleh wacana dan bahasa (2002:45). Matriks ini merupakan teori tentang pandangan-pandangan masyarakat tentang seks dan gender serta institusi sosial yang mempengaruhinya (Beltran, 2000:4). Hal ini berkaitan dengan bahasa (dan wacana) sebagai pangatur standar normatif dimana diri divalidasi dan diri referensial diatur sebagai standar identitas normatif. Matriks sosial juga bekerja dengan sanksi sosial terhadap perilaku yang dianggap menyimpang, sehingga konsensus terhadap kategori dasar terus-menerus 
ditopang melalui monitoring terhadap refleksi diri.

Salih (2002:61 -62) memberikan contoh yang mirip dengan penjelasan teori performativitas linguistik di atas. Ujaran 'ini perempuan' bukanlah pernyataan faktual, melainkan anggapan yang dilekatkan pada perbedaan laki-laki dan perempuan. Ujaran tersebut memaksa subjek menjadi perempuan yang sesuai norma seksual dan gender sesuai konvensi dalam rangka memenuhi matriks heteroseksual. Dengan demikian, matriks heteroseksual bertindak sebagai otoritas penentu standar normatif identitas dan konstruksi gender yang dapat diterima.

Anggota masyarakat menentukan tindakan mereka dan tindakan anggota lain dengan mengacu dan mengutip normanorma pengetahuan yang menjadi bagian matriks heteroseksual. Melalui standar nilai tersebut, penghakiman terhadap individu atau kelompok di luar konvensi diniscayakan. Kekuasaan matriks heteroseksual ini terus dipertahankan dan diperkuat melalui kontrol reflektif terhadap identitas gender.

\section{METODE PENELITIAN}

Makalah ini menggunakan metode kajian pustaka. Data-data primer dan sekunder didapatkan dari studi kepustakaan. Data primer didapat dari cerpen SdMSO karya Djenar Maesa Ayu sementara data sekunder diperoleh dari pustaka pendukung lain yang dapat dijangkau peneliti baik dalam bentuk cetak maupun e-book. Penelitian dimulai dari pembacaan cerpen SdSMO secara heuristik kemudian dilakukan pembacaan ulang secara hermeneutik. Selama proses tersebut dilakukan pencatatan-pencatatan berkaitan dengan deskripsi naratif maupun dialog dalam cerpen yang berkaitan dengan masalah penelitian. Data yang didapat kemudian dianalisis dengan menggunakan teori queer. Selanjutnya hasil analisa disajikan dalam bentuk artikel berlanggam bebas seperti pada artikel ini.

\section{PEMBAHASAN}

\section{Ketaksaan Gender dan Strategi Djenar dalam Mengkonstruksi Identitas Queer dalam Cerpen SdMSO}

Penggunaan teori queer sebagai pisau analisis dalam membedah cerpen SdSMO dilakukan karena melalui tokoh utamanya Djenar (seperti Butler) membongkar konsep wacana gender yang tertulis di tubuh (written in body). Sejak awal hingga akhir, tidak ada satu pun bagian cerita yang dengan tegas menyatakan identitas gender tokoh utama. Djenar seakan sengaja menyembunyikan identitas gender tokoh 'saya' dalam cerpen tersebut. Mengapa hal ini dilakukan Djenar akan kita bahas setelah membuktikan bahwa tokoh 'saya' dalam cerpen tersebut adalah seorang queer.

Ada beberapa jejak yang muncul dalam cerita yang membuktikan bahwa tokoh ini bukan beridentitas gender yang dikenal sebagai oposisi biner dalam heteronormativitas, laki-laki dan perempuan. Bukti pertama adalah dilucuti nuansa gender pada kata. Pada tokoh utama 'saya' ini Djenar melekatkan kata yang kita secara umum dikenal memiliki nuansa maskulin maupun feminin, Misalnya kata / gagah/ sekaligus / gaun/ dan / perhiasan/. Kata /gagah/ cenderung membuat kita memfantasikan sosok seorang lelaki, begitu pun dengan /gaun/ dan / perhiasan/ yang cenderung membuat kita mengaitkannya dengan perempuan. Melekatkan dua kata seperti ini mengindikasikan bahwa tokoh 'saya' dalam cerpen SdMSO memiliki kadar maskulin dan feminin sekaligus. Pergerakan yang cair antara maskulinitas dan femininitas dalam tokoh di cerpen SdMSO ini merupakan upaya awal untuk menghapuskan sekat-sekat gender. Usaha lain dilakukan melalui pelucutan nuansa makna dalam kata, karena kata sesungguhnya tidak memiliki jenis kelamin. 
Pendapat tentang identitas queer tokoh 'saya' di atas akan menjadi lemah jika tidak didukung oleh data lain. Kadar maskulinitas dan feminitas masih mungkin dimiliki oleh lelaki maupun perempuan. Oleh karena itu kontradiksi dari dua teks berikut akan melengkapi bukti bahwa tokoh dalam cerpen ini adalah seorang queer.

"kalau saya dapat undangan pesta dan perlu gaun malam lengkap dengan perhiasan, saya utarakan. Kenapa harus sungkan?" (Ayu, 2016:76)

Lalu perhatikan juga kutipan berikut. "...Membuat darah saya berdesir dan mengisyaratkan suatu kenikmatan. Malammalam panjang. Kontraksi dahsyat di tengah selangkangan. Yang nyatanya berakhir dengan rasa mual. Ereksi yang tidak lama kekal. Reaksi yang membuat waktu berjalan bagai tak berujung pangkal. Dan saat itulah alarm dalam tubuh saya mengisyaratkan segala rencana kencan lanjutan mutlak batal." (Ayu, 2016:81--82)

Kutipan pertama memberikan informasi bagi kita bahwa tokoh 'saya' adalah orang yang pergi ke pesta dengan menggunakan 'gaun malam lengkap dengan perhiasan.' Sejenak kita akan langsung terpikir bahwa tokoh ini adalah perempuan, namun dalam konteks karya yang telah melucuti nuansa gender dalam kata hal ini tidak menjadi mutlak. Tokoh 'saya' masih memiliki kemungkinan sebagai seorang drag (waria), transgender, atau gender lain di luar lelaki dan wanita.

Kutipan kedua memberikan kontradiksi untuk menggugat pendapat yang menganggap identitas gender tokoh aku adalah perempuan. Gaya narasi Djenar di sini menunjukkan bahwa pengalaman seksual tersebut dirasakan oleh sang tokoh 'saya'. Salah satu kuncinya adalah frasa terakhir yang menyebut "dan saat itu lah alarm dalam tubuh saya ...". Pengalaman seksual yang digambarkan
Djenar sebagai "kontraksi dahsyat di tengah selangkangan" dan kata / ereksi/ tidak mungkin di rasakan oleh orang yang tidak memiliki penis. Pengalaman seksual wanita disebut orgasme dan kontraksi terjadi di area sekitar pinggang. Dapat disimpulkan bahwa tokoh 'saya' yang mengalami pengalaman seksual tersebut memiliki penis sebagai organ seksualnya.

Kedua kutipan tersebut membuktikan bahwa ada 'kekacauan' (ketaksaan) identitas gender pada tokoh utama cerpen ini. Karakter yang memakai 'gaun malam lengkap dengan perhiasan' ke pesta, tetapi juga memiliki penis sebagai organ seksual. Memang tidak mungkin menegaskan bahwa tokoh 'saya' adalah transgender atau drag karena ketiadaan data pendukung. Akan tetapi dengan dihilangkannya batas gender dalam tokoh, bisa dipastikan tokoh 'saya' adalah seorang beridentitas queer.

Jika penyampaian di atas masih menyisakan keraguan, ada baiknya untuk menyimak kutipan pada bagian menjelang akhir cerita berikut.

"Mungkin jika bukan karena penyakit yang datang tanpa bisa saya larang tidak saya idap sekarang, saya hampir percaya pada pendapat sebagian orang yang tiap bagiannya menyatu menjadi satu pendapat utuh bahwa tindakan saya menyimpang. Mungkin jika bukan karena saya tergeletak bagai anjing kusta saya hampir beralih dari apa yang selama ini saya percayai dan nikmati dengan hati lapang. Karena, ketika saya positif mengidap HIV ternyata saya masih punya banyak teman setia menyiapkan air hangat untuk bilas badan." (Ayu, 2016:82)

Frasa "Saya hampir percaya pada pendapat sebagian orang yang tiap bagiannya menyatu menjadi satu pendapat utuh bahwa tindakan saya menyimpang" merupakan penegasan bahwa tokoh aku adalah seorang beridentitas gender queer. / Menyimpang/ menjadi kata kunci 
bagi penegasan queer karena makna dasar queer sendiri adalah bertentangan dengan konvensi atau menyimpang. Hal ini bisa saja merujuk pada aktivitas seks bebas yang dilakukannya, tapi jika melihat secara komprehensif pada keseluruhan hasil analisa teks, maka bisa disimpulkan juga bahwa sang tokoh memiliki orientasi berbeda. Hal ini disampaikan di akhir sebagai kejutan yang disiapkan Djenar untuk pembacanya. Strategi ini kemungkinan dilakukan setidaknya untuk dua hal berikut.

1. Melepaskan kekangan wacana kekuasaan untuk konstruksi gender dari tokoh utama aku dengan secara kontradiktif melekatkan secara berbarengan katakata yang direferensikan pada gender tertentu misalnya/gagah/ dan /gaun/. Langkah ini merupakan perlawanan terhadap denaturalisasi queer yang dikonstruksi wacana heteronormativitas.

2. Deskripsi identitas tokoh yang serba sumir seperti ditemukan dalam gambaran ereksi yang secara biologis hanya mungkin dirasakan laki-laki dengan narasi lain yang menjelaskan kebiasaan tokoh utama menggunakan gaun mencegah pembaca untuk memutuskan identitas gender sang tokoh utama. Strategi narasi ini dilakukan untuk berdamai dengan sidang pembaca yang masih menganggap queer sebagai hal yang tabu.

\section{Resistansi Tokoh "Saya' dalam Cerpen SdMSO terhadap Matriks \\ Heteroseksualitas}

Setelah diyakini bahwa tokoh tersebut adalah seorang queer maka menarik untuk membahas bagaimana cerpen ini mempermasalahkan cara kerja matriks heteroseksual. Seperti telah dijelaskan di atas, cara kerja bahasa dalam mengisi matriks heteroseksual melalui wacana. Wacana berupa anggapan yang dilekatkan pada perbedaan laki-laki dan perempuan. Ujaran tersebut memaksa subjek menjadi laki-laki atau perempuan yang sesuai norma seksual dan gender sesuai konvensi dalam rangka memenuhi matriks heteroseksual. Cara kerja matriks heteroseksual dalam cerpen ini digambarkan dalam kalimat pembuka sebagai berikut.

"sebagian orang menganggap saya munafik. Sebagian lagi menganggap saya pembual. Sebagian lagi menganggap saya sok gagah. Sebagian lagi menganggap saya sakit jiwa. Sebagian lagi menganggap saya murahan!" (Ayu, 2016:73)

Juga kutipan berikut.

Namun dari sanalah segalanya berpangkal. Semua yang saya lakukan itu dianggap tidak benar. Sebagian orang menganggap saya munafik karena tidak pernah mengakui kalau saya punya pacar. Sebagian lagi menganggap saya pembual setiap kali saya bilang hubungan kami sebatas pertemanan. Sebagian lagi menganggap saya sok gagah karena mereka berpikir saya tidak mau mengakui kalau saya sebenarnya mencintai seseorang. Sebagian lagi menganggap saya sakit jiwa karena berteman dengan begitu banyak orang. Sebagian lagi menganggap saya murahan karena saya bisa ditiduri tanpa harus ada komitmen percintaan bahkan dalam satu hari bisa dengan orang yang berlainan." (Ayu, 2016:79)

Matriks sosial juga bekerja dengan sanksi sosial terhadap perilaku yang dianggap menyimpang seperti telah dijelaskan di atas. Anggapan orang lain tentang diri tokoh 'saya' yang 'murahan', 'munafik', 'sok gagah', dan'sakitjiwa' muncul karena tindakan yang dilakukannya tidak sesuai dengan norma yang ditetapkan oleh heteronormativitas untuk mengisi matriks heteroseksual. Sanksi sosial pun dilakukan melalui pembentukan opini yang menekan tokoh 'saya' untuk mengisi matriks sosial yang sesuai dengan 
norma heteroseksual. Hukuman ini dalam ruang sosial mewujud dalam pergunjingan seperti pada kutipan berikut.

"Perbuatan yang saya jalani dengan penuh kewajaran tiba-tiba berubah menjadi perdebatan. Semua orang merasa lebih tahu dibanding diri saya sendiri. Beberapa bagian dari mereka sibuk dengan pendapatnya masing-masing dan lebih luarbiasa lagi mereka bisa membahas perihal saya ini berjam-jam, berhari-hari, berminggu-minggu, berbulanbulan, bertahun-tahun, sementara temanteman saya semakin banyak, silih berganti tanpa henti dan ini membuat mereka punya materi yang lebih dari cukup untuk terus mempergunjingkan saya seolah tidak ada hal lain yang lebih pantas diangkat sebagai tema. Mereka bergunjing lewat telepon. Mereka saling bertukar pesan lewat SMS. Mereka saling mengirim surat elektronik. Mereka saling bertukar pendapat di kafe-kafe. Di rumah. Di kantor. Di pertokoan. Di restoran. Apalagi jika secara kebetulan kami bertemu dalam satu kesempatan dengan membawa teman baru. Pembicaraan mendadak berhenti. Mereka sembunyi-sembunyi bertukar senyum. Mereka sembunyi-sembunyi bermain mata. Mereka sembunyi-sembunyi mengirim pesan SMS. Mereka saling berbisik dengan ekspresi wajah yang sulit untuk diterjemahkan. Kadang ada satu dua kalimat yang terdengar dan sudah cukup bagi saya untuk merangkumnya utuh menjadi satu bagian." (Ayu, 2016:78-79)

Secara sosial, wacana mengenai penyimpangan tokoh disebarkan dari satu anggota masyarakat ke anggota lainnya. Hal ini membentuk wacana sosial yang ditujukan untuk mengakumulasikan tekanan sosial bagi anggota yang tergolong queer. Kutipan di atas menunjukkan bagaimana matriks heteroseksual bekerja pada tokoh 'saya' dalam cerpen SdMSO.
Berbeda dengan kecenderungan karya dengan tema serupa, tokoh 'saya' dalam cerpen SdMSO ini tidak menunjukkan rasa depresi dan penderitaan. Kalimat "saya tidak merasa..." berkaitan dengan label yang dilekatkan padanya menunjukkan rasa nyaman dirinya menjadi seorang queer. Tokoh "aku' malah menemukan bahwa apa yang dilakukan oleh pihak-pihak lain dalam cerita tidak lebih baik dari apa yang ia dan temantemannya lakukan.

"Hal-hal seperti ini tidak saya temukan pada sebagian orang yang menganggap saya munafik, pembual, sok gagah, sakit jiwa dan murahan itu. Sebagian dari mereka malah sering saya dapati tidak lagi bertegur sapa sama sekali dengan teman lamanya. Biasanya itu disebabkan karena hubungan mereka yang sembunyi-sembunyi dengan si $A$ ketahuan oleh si B. Setelah putus denga si B ternyata ketahuan pula lah si A berteman dengan perempuan lain." (Ayu, 2016:81).

Asumsi 'saya' dalam kutipan di atas menunjukkan kecenderungan resistansi terhadap kerja matriks heteroseksual. Ia "tetap menghargai sebuah pilihan" yang secara tidak langsung mengharapkan perlakuan serupa terhadap pilihannya. Akan tetapi, meski "heran" ia "tetop tidak berani menganggap mereka munafik, pembual, sakit jiwa, sok gagah, atau murahan" karena berhadapan dengan kekuasaan. Hal ini merupakan perwujudan sintesa Rubin tentang hubungan asimetris gender dan marginalisasi terhadap gender minoritas. Tokoh 'saya' bahkan tidak memiliki kedudukan setara untuk memberikan klaim terhadap sesuatu yang dianggapnya menyimpang. Hal ini terjadi karena orientasi heteroseksual mendapat kedudukan sebagai privileged orientation.

Puncak dari wujud resistensinya tersebut digambarkan dalam akhir cerpen SdMSO. Tokoh 'saya' menderita penyakit 
HIV dan hampir percaya pada tekanan wacana sosial yang diberikan kepadanya. Namun hal tersebut digagalkan karena ternyata masih banyak 'teman yang setia' mendampinginya.

"ketika saya positifHIV ternyata saya masih punya banyak teman yang setia menyiapkan air hangat untuk bilas badan. Mengirim makan siang. Menemani makan malam. Mendongeng tentang sebuah cerita lucu di satu kafe. Bercerita tentang satu film yang baru saja diputar, membayar ongkos perawatan, ketika semua orang sibuk bergunjing atas akibat yang saya terima karena saya munafik. Pembual. Sok gagah. Sakit jiwa. Murahan!" (Ayu, 2016:83).

Sebagai penutup, cerpen ini seakan ingin menyampaikan bahwa solidaritas antaranggota queer mampu mengatasi tekanan psikologis yang dihadapi dari lingkungan sosial. Sebaliknya hukuman sosial makin menguatkan keyakinan akan identitas gendernya tersebut. Hingga akhir pun tokoh 'saya' dalam cerpen ini menunjukkan resistensinya terhadap kerja matriks heteroseksual.

\section{PENUTUP}

Analisis terhadap cerpen SdMSO karya Djenar Maesa Ayu dengan menggunakan teori queer menghasilkan simpulan sebagai berikut.

1. Strategi penceritaan dalam SdSMO mendenaturalisasi heteronormativitas melalui pelucutan nuansa gender dalam kata untuk melepaskan konstruksi gender wacana heteronormativitas dari tokoh utama aku. Penggambaran gender sebagai sesuatu yang taksa ini berfungsi meredam resistansi dari sidang pembaca terhadap teori queer di lingkungan yang belum cukup kondusif untuk disampaikan.
2. Tokoh saya dalam cerpen SdSMO merupakan representasi perlawanan terhadap cara kerja matriks heteroseksual.

\section{DAFTAR PUSTAKA}

Ayu, Djenar Maesa. 2016. Saya di Mata Sebagian Orang. Jakarta: PT Gramedia Pustaka Utama.

Alimi, M.Y. 2004. Dekonstruksi Seksualitas Poskolonial: Dari Wacana Bangsa Hingga Wacana Agama. Yogyakarta: LkiS.

Barry, P. 2010. Pengantar Komprehensif Teori Sastra dan Budaya terj. Widayawati dan Setyorini. Yogyakarta: Jalasutra.

Beltran, Patricia Soley. 2000. Transexualismand the Heterosexual Matrix: A Critical and empirical Study of Judith Butler's Perfomative Theory of Gender. United Kingdom. Tesis pada Universitas Edinburgh.

Butler, Judith. 2002. Gender Trouble. New York: Taylor and Francis e-Library.

Faruk. 2002. Beyond Imagination: Sastra Mutakhir dan Ideologi. Yogyakarta: Gama Media.

Jackson, Stevi dan Jackie Jones. 2009. Pengantar Teori-Teori Feminis Kontemporer. Yogyakarta dan Bandung: Jalasutra.

Jagger, G. 2008. Judith Butler Sexual Politics, Social Change, and The Power of Performative. New York: Routledge.

Pilcher, I.W. Jane. 2004. Fifty Key Concepts in Gender Studies. London: SAGE Publications.

Prabasmoro, Aquarini Priyatna. 2007. Kajian Budaya Feminis Tubuh, Sastra, dan Budaya Pop. Yogyakarta dan Bandung: Jalasutra.

Salih, Sara. 2002. Judith Butler. London: Routledge. 